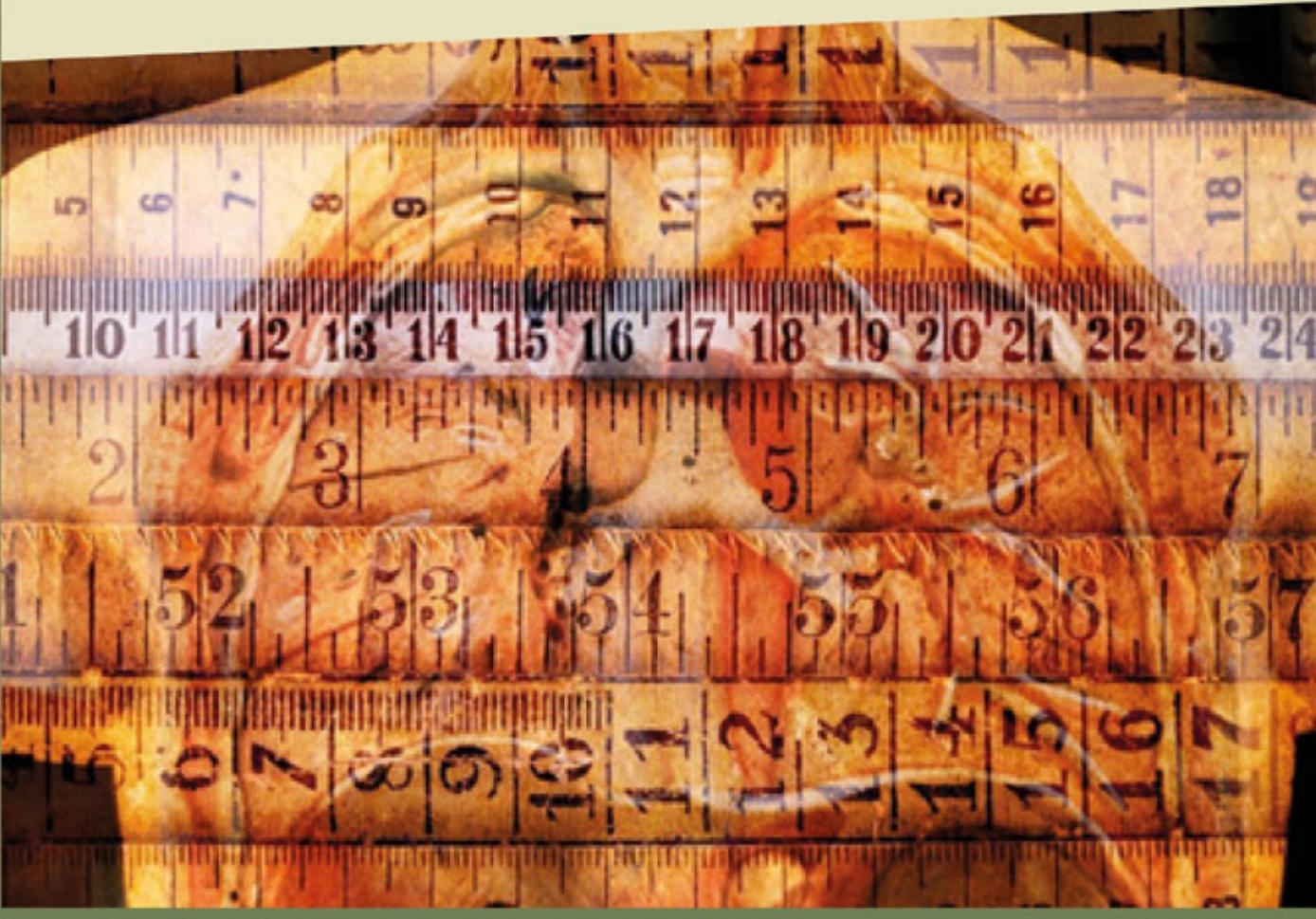

\title{
Measuring difference, numbering normal
} Setting the standards for disability in the interwar period

COREEN MCGUIRE 


\section{MEASURING DIFFERENCE, NUMBERING NORMAL}

\section{MANCHESTER 1824}

Manchester University Press 


\title{
DISABILITY
}

\author{
Series editors \\ Dr Julie Anderson, Professor Walton O. Schalick, III
}

This series published by Manchester University Press responds to the growing interest in disability as a discipline worthy of historical research. The series has a broad international historical remit, encompassing issues that include class, race, gender, age, war, medical treatment, professionalisation, environments, work, institutions and cultural and social aspects of disablement including representations of disabled people in literature, film, art and the media.

\author{
Already published \\ Deafness, community and culture in Britain: leisure and cohesion, 1945-1995 \\ Martin Atherton
}

Disability in industrial Britain: a cultural and literary history of impairment in the coal industry, $1880-1948$

Kirsti Bohata, Alexandra Jones, Mike Mantin and Steven Thompson

Disability and the Victorians: attitudes, interventions, legacies lain Hutchinson, Martin Atherton and Jaipreet Virdi (eds)

Rethinking modern prostheses in Anglo-American commodity cultures, 1820-1939

Claire L. Jones (ed.)

Destigmatising mental illness? Professional politics and public education in Britain, 1870-1970 Vicky Long

Intellectual disability: a conceptual history, I 200-1900

Patrick McDonagh, C. F. Goodey and Tim Stainton (eds)

Fools and idiots? Intellectual disability in the Middle Ages Irina Metzler

Framing the moron: the social construction of feeble-mindedness in the American eugenics era Gerald V. O'Brien

Recycling the disabled: army, medicine, and modernity in WWI Germany Heather R. Perry

Shell-shocked British Army veterans in Ireland, 19 18-39: a difficult homecoming Michael Robinson

Eradicating deafness? Genetics, pathology, and diversity in twentieth-century America Marion Andrea Schmidt

Disability in the Industrial Revolution: physical impairment in British coalmining, I780-1880

David M.Turner and Daniel Blackie

Worth saving: disabled children during the Second World War

Sue Wheatcroft 


\section{MEASURING DIFFERENCE, NUMBERING NORMAL}

\section{SETTING THE STANDARDS FOR DISABILITY INTHE INTERWAR PERIOD}

Coreen McGuire

Manchester University Press 
The right of Coreen McGuire to be identified as the author of this work has been asserted by her in accordance with the Copyright, Designs and Patents Act 1988.

An electronic version of this book is also available under a Creative Commons (CC-BY) licence, which permits distribution and reproduction provided the author(s) and Manchester University Press are fully cited and any changes are acknowledged.

Details of the licence can be viewed at https://creativecommons.org/licenses/by/4.0/

Published by Manchester University Press

Altrincham Street, Manchester M1 7JA

www.manchesteruniversitypress.co.uk

British Library Cataloguing-in-Publication Data

A catalogue record for this book is available from the British Library

ISBN 9781526143174 hardback

ISBN 9781526143167 open access

First published 2020

The publisher has no responsibility for the persistence or accuracy of URLs for any external or third-party internet websites referred to in this book, and does not guarantee that any content on such websites is, or will remain, accurate or appropriate.

Typeset by Newgen Publishing UK 